GLOBAL JOURNAL OF MEDICAL SCIENCES VOL 10, NO. 1\&2, 2011: 29-36

COPYRIGHT@ BACHUDO SCIENCE CO. LTD PRINTED IN NIGERIA. ISSN 1596-2911

www.globaljournalseries.com; Email: info@globaljournalseries.com

\title{
PREVALANCE OF ALCOHOL ABUSE IN CALABAR SOUTH LOCAL GOVERNMENT AREAS CROSS RIVER STATE
}

\section{NELSON CHUKWUDI OSUCHUKWU AND EASTER CHUKWUDI OSUCHUKWU}

\begin{abstract}
This study examined the prevalence of alcohol abuse in Calabar South, Local Government Area of Cross River State, Nigeria. Unlike earlier studies of alcohol use in Nigeria, the study focused on a segment of the population that is difficult to reach and probably at high risk of alcohol and drug abuse. In addition, the focus of this study was on both western and the traditional alcohol beverages. The sample consisted of 400 respondents aged 10-50 years resident in Calabar South. Life time consumption of alcohol was reported by $98.5 \%$ of the respondents. Beer was the most often consume alcoholic drinks in the study population by the male while wine was for female, $64 \%$ of males took beer while $36 \%$ of females took wine. the odds of taking alcoholic drink increased with age. The consumption of alcohol was described as very harmful to health by $48 \%$ of the sample Analysis of the data showed that the factors that mostly influenced alcohol drinking were its availability which stood at $52.75 \%$, peer groups influenced $27.25 \%$, mass media advent $7.5 \%$, home $9.5 \%$ and school $3.0 \%$. The study also showed that alcohol consumption had effect on the social behaviour of the people of Calabar South. Decreased work performance $77.25 \%$, increase in violence and crime $77 \%$, poverty $50.75 \%$, wife and childbearing $73.75 \%$, increase in accident rate $80.5 \%$, children inability to continue schooling $83.5 \%$ Nigerian culture, it appears that there is a culture of alcohol implicitly institutionalized that one could easily brand it as a norm to drink alcohol across the whole social spectrum with the student population constituting a significant proportion of the risk group (Ifeagwazi,2007).
\end{abstract}

KEYWORDS: Prevalence, alcohol abuse, alcohol, Calabar South.

\section{INTRODUCTION}

The misuse of alcohol is a far greater social problem than the misuse of other drugs (Udoh, 2005) World Health Organization claims that alcoholism is the world's third major disease and is twenty times more prevalent than all other drugs combined. (Priest, 2008). Alcoholism causes deterioration in the personal health and damage to community life. The revenue collected from those who drink alcohol could almost be offset by the national cost of unemployment, disease, poverty, delinquency, family welfare and accidental death or injury resulting from over indulgence (WHO, 2008). Alcohol produces several dependence in one in five of all drinkers as stated by Priest (2008). He further stated that alcoholics occupy about 7,500 mental hospital beds and they form a fair proportion of those who are homeless or who use reception centers. In Britain alone, there are about $350.000-500,000$ alcoholics.

Alcoholism is a complex condition described by many as a social disease characterized by the individual's inability to settle in himself or his environment without resorting to excessive amount of alcohol. (Gurejie,2009).There is no single cause. It seems to be an expression of character and social attitude. he results however, are indisputable, and the sufferer and his family become a public health problem and a community responsibility. The alcoholic not only suffers varying degree of economic decline, degradation and physical illness and faces the possibility of insanity and death but also runs the risk of damaging the

Nelson Chukwudi Osuchukwu, Department of Public Health, University of Calabar, Calabar. Nigeria.

Easter Chukwudi Osuchukwu, School of Nursing, University of Calabar, Calabar, Nigeria. 
health and happiness of his or her family (Priest, 2008).

Alcohol which has become an integral part of human culture, past and present with special reference to the Nigerian culture, it appear that there is a culture of alcohol implicitly institutionalized that one could easily brand it as a norm to drink alcohol across the whole social spectrum with the student population constituting a significant proportion of the risk group (Charles, 2007). The alcohol consumption patterns have changed because of societal changes that resulted in stressors and tension, permissive attitude towards alcohol use, alcohol availability and the absence of alternative mechanism of relieving tension. This finding suggested a need for tagged prevention programmes and comprehensive strategies aims at preventing alcohol misuse among young people. Theory based interventions for moderating alcohol consumption, including innovative ways of reducing cultural stress and tension, modifying prevalent attitudes towards alcohol use, managing the availability of alcohol and finding alternative for obtaining psychic release here has been proposed.

\section{MATERIALS AND METHODS}

The study is a cross-sectional descriptive study. The study aims at ascertaining the prevalence of alcohol abuse in Calabar South LGA of Cross River State. The survey described and quantifies the distribution of the epidemiologic variable in the study population at a point in time. It covers the socio economic aspect and behaviour of the people in the population.

The target population for the study consists of the total population of males and females and 10-50 years. The total population of the local government area is 8444 NPC (1991). Using the names of all the nine villages written on a piece of paper differently, wrapped and put in a box after which the box was shaken vigorously to ensure randomization. Five papers were taken out of the box one after the other without replacement. The five villages drawn from the box constituted the study population. Responses to the questions were analyzed using the descriptive statistical method.

\section{RESULTS}

Table1 shows the sources of alcoholic drinks taken by respondent, $26(6.5 \%)$ had their source from gifts, 28 (7\%) drink from family bar,
$314(78.0 \%)$ buy from sellers, while $32(8 \%)$ produce the drink locally.

Furthermore, table 2: Shows the distribution of categories of alcohol drinking of respondent. It is seen that pleasure drinkers were 147 or $36.75 \% 11(2.75 \%)$ were crisis period drinkers,164 (41\%) represent social drinkers 33 $(8.25 \%)$ were addicted drinkers, while 45 or $(11.25 \%)$ were habitual drinkers.

Table 3: Shows the period of the day in which respondent take alcoholic drinks mostly. In the Morning 76 (19\%). 101 (25.25\%) in the afternoon, $152(38 \%)$ take in evening while 71 or 17.75 take in the night.

Table 4: Represent the types of alcohol drinks taken by respondents. Those that take whisky were 10 (2.5\%), 12 (13\%) take brandy, 4 (1\%) take Gin, $56.25 \%$ take bear. $52(13 \%)$ take stout while 18 or $4.5 \%$ of respondent take local gin (Ufofop) which is a distillate of palm wine.

Table 6: Indicates the ranking of the various brands of alcoholic drinks according to order of preference by Gender. Table 7: shows the reasons why respondents take an alcohol. Table 8: Represent the effect of alcohol consumption on the social behaviour of the respondent.

Table 9: shows the factors associated with alcohol consumption.

Table 10: indicates the risk associated with alcohol.

\section{DISCUSSION}

The study indicates that drinking among the people of Calabar South Local Government Area starts early in life. This finding agrees with Ojiji (2005) who found that mothers who brew the traditional beverages give alcohol to very young children. Another study conducted by Oladimeji (2006) showed that drinking among Nigeria adolescent begins between the ages of $11-15$ years.

The study further showed a higher percentage of alcohol use of $70.5 \%$ for men and $29.5 \%$ for women. This confirms the report of Abiodun (2007) on alcohol related problems in primary care patients in Nigeria. He found that those with alcohol problem were significantly more likely to be men than women as men are more alcohol dependent than women.

This study also indicated that alcohol dependent were more in individuals who were separated. Divorced or widowed. This finding agrees with Okafor (2008) and Abiodun (2009) 
who independently observed that alcohol abuse is most likely in individuals who are separated, divorce or widowed but less seem among individuals who were above fifty years of age. This study also showed that alcoholic drinks were mostly taken in the evening in the study area where socialization is high. This finding agrees with the result of Obot (2006), on drinking behaviours and attitudes in Nigeria where alcohol was heavily consumed in TIV land during the evening hours. Beer consumed by $50.25 \%$ of respondents is certainly the most popular alcoholic drink in Calabar South Local Government Area. Though, the study also indicated that the traditional beverages are also very popular among this study population. This finding tally with that of Obot (2006), on alcohol use by adolescents, he found that beer was the popular drink. This study revealed that respondents have different reasons for taking alcohol, for healing of some ailments, they were $368(92 \%)$ of the respondents. According to Ironbar (2006) alcohol is used as sedative or tranquiller by some individuals or as part of diets for diabetic patients or as an aid in treating some digestive diseases. Priest (2009), in his findings concluded that alcohol can be regarded as a food providing fuel for bodily combustion and that is also gives comfort to the elderly. Gureje (2007) observed that before anesthetics were discovered, alcohol was used in large amounts to produce sleep or complete stupor and until recently, in small does as an emergency stimulant.

The result of this study showed that excessive drinking of alcohol produces a variety of closely inter related social problems in the study area. Alcohol related illness and death increase directly with the amount consumed. Wife and child battering were $73.75 \%$, unwanted pregnancies $20.75 \%$, sexual promiscuity $60 \%$, and increase in legal cost of drink related offence $20.5 \%$. According to Ging (2010), his study on international challenges of drug abuse concluded that alcohol abuse caused deterioration in personal health and damage to community life, the revenue collected from those who drink alcohol could almost be oft set by the national cost of employment, disease, poverty, delinquency, family welfare and accidental death or injury resulting from over indulgence. According to Desire (2010) heavy drinking affects work performance in a number of negative ways, drinkers are more frequently absent, less efficient, have more accidents at work and also show maladjustment with other workers which lead to over all decreased performance.

\section{RECOMMENDATION}

Government should increase the effort to ensure that drunken drivers are not on the road and bars should not be allowed at motor parks. The slogan "if you drink don't drive and if your drive don't drink" should be accepted by all and sundry. Practices that involve drinking at funeral and other occasions should be discouraged rather than glorify those who lavishly provide alcohol on these occasions. The practice should be frowned at.

Government should mount a serious campaign to educate people on the health hazards of alcohol and to dissuade people to drop the habit of taking alcohol. School curricula should be reviewed to include modules on prevention and management of alcohol abuse.

Finally communities should fashion out strategies to curb alcohol problems and encourage its members to participate in activities that tend to promote healthy life style. 
TABLE 1: Sources of alcohol drink taken by respondents.

\begin{tabular}{|l|l|l|}
\hline Sources & No. of respondents & Percent \\
\hline Gift & 26 & 6.5 \\
\hline Family bar & 28 & 7 \\
\hline Bought from sellers & 314 & 78.5 \\
\hline Produced locally & 32 & 8 \\
\hline Total & 400 & 100 \\
\hline
\end{tabular}

TABLE 2: Categories of Alcohol users

\begin{tabular}{|l|l|l|}
\hline Categories & No. of respondent & Percent \\
\hline Pleasure drinkers & 147 & 36.75 \\
\hline Crisis period drinkers & 11 & 2.75 \\
\hline Social drinkers & 164 & 41 \\
\hline Addicted drinkers & 33 & 8.25 \\
\hline Habitual drinkers & 45 & 11.25 \\
\hline Total & 400 & 100 \\
\hline
\end{tabular}

TABLE 3: Period Alcohol is mostly taken.

\begin{tabular}{|l|l|l|}
\hline Period & No. of respondents & Percent \\
\hline Morning & 76 & 19 \\
\hline Afternoon & 101 & 25.25 \\
\hline Evening & 152 & 38 \\
\hline Night & 71 & 17.75 \\
\hline Total & 400 & 100 \\
\hline
\end{tabular}


TABLE 4: Types of alcoholic drinks taken by respondent

\begin{tabular}{|l|l|l|}
\hline Alcoholic Drink & No. of respondent & Percent \\
\hline Whiskey & 10 & 2.5 \\
\hline Brandy & 12 & 3 \\
\hline Gin & 4 & 1 \\
\hline Wine & 56 & 14 \\
\hline Palm wine & 47 & 11.75 \\
\hline Beer & 201 & 50.25 \\
\hline Stout & 52 & 13 \\
\hline Ufofob & 18 & 4.5 \\
\hline Total & 400 & 100 \\
\hline
\end{tabular}

TABLE 5: Ranking of the various brands of Alcoholic beverages according to order of preference by gender.

Male $\mathrm{N}=282 \quad$ Female $\mathrm{N}=118$

\begin{tabular}{|l|l|l|l|l|l|l|l|}
\hline $\begin{array}{l}\text { Alcoholic } \\
\text { Drink }\end{array}$ & $\begin{array}{l}\text { No. of } \\
\text { Respondents }\end{array}$ & Percent & Ranking & $\begin{array}{l}\text { Alcoholic } \\
\text { Drink }\end{array}$ & $\begin{array}{l}\text { No. of } \\
\text { Respondents }\end{array}$ & Percent & Ranking \\
\hline Beer & 181 & 64 & 1 & Wine & 42 & 36 & 1 \\
\hline Stout & 31 & 11 & 2 & $\begin{array}{l}\text { Palm } \\
\text { wine }\end{array}$ & 23 & 19.4 & 2 \\
\hline $\begin{array}{l}\text { Palm } \\
\text { wine }\end{array}$ & 24 & 8.5 & 3 & Stout & 21 & 18 & 3 \\
\hline Ufofob & 15 & 5.3 & 4 & Beer & 20 & 17 & 4 \\
\hline Wine & 14 & 4.9 & 5 & Brandy & 4 & 3 & 5 \\
\hline Brandy & 8 & 2.8 & 6 & Ufofob & 3 & 2.5 & 6 \\
\hline Whisky & 7 & 2.5 & 7 & Whisky & 3 & 2.5 & 7 \\
\hline Gin & 2 & 0.7 & 8 & Gin & 2 & 1.6 & 8 \\
\hline
\end{tabular}


TABLE 6: Reasons for taking alcohol.

\begin{tabular}{|l|l|l|}
\hline Reason & No. of respondents & Percent \\
\hline Healing & 368 & 92 \\
\hline Peer group acceptance & 239 & 59.75 \\
\hline Awake during Examination & 182 & 45.5 \\
\hline Desire for new experience & 154 & 38.5 \\
\hline Imitation of elders & 131 & 32.75 \\
\hline Overcoming shyness & 288 & 72 \\
\hline Sleep aid & 102 & 25.5 \\
\hline Overcome fatigue and boredom & 297 & 74.25 \\
\hline
\end{tabular}

* Multiple responses allowed.

TABLE 7: Effect of alcohol consumption on the social behavior of the respondents $\mathrm{N}=400$

\begin{tabular}{|l|l|l|}
\hline Effect & No. of respondents & Percent \\
\hline Wife and child battering & 295 & 73.75 \\
\hline Unwanted pregnancies & 83 & 20.75 \\
\hline Poverty & 203 & 50.75 \\
\hline Loss of Job & 197 & 49.25 \\
\hline Decrease eligibility of loan & 75 & 18.75 \\
\hline Increased in accident rate & 322 & 80.5 \\
\hline $\begin{array}{l}\text { High degree of depression } \\
\text { and suicide }\end{array}$ & 147 & 36.75 \\
\hline $\begin{array}{l}\text { Children inability to continue } \\
\text { schooling }\end{array}$ & 334 & 83.5 \\
\hline $\begin{array}{l}\text { Increase in legal cost of } \\
\text { drink related offences }\end{array}$ & 82 & 20.5 \\
\hline $\begin{array}{l}\text { Absence of essential } \\
\text { necessities in homes }\end{array}$ & 68 & 17 \\
\hline
\end{tabular}




\begin{tabular}{|l|l|l|}
\hline $\begin{array}{l}\text { Increase in violence and } \\
\text { crime }\end{array}$ & 308 & 77 \\
\hline Decrease work performance & 311 & 77.75 \\
\hline Sexual promiscuity & 240 & 60 \\
\hline
\end{tabular}

* Multiple responses allowed.

TABLE 8: Factors that promote alcohol drinking

\begin{tabular}{|l|l|l|}
\hline Factor & No. of Respondents & Percent \\
\hline Home & 38 & 9.5 \\
\hline School & 12 & 3 \\
\hline Mass media advert & 21 & 5.25 \\
\hline $\begin{array}{l}\text { Insufficient number of } \\
\text { medical personnel }\end{array}$ & 9 & 2.25 \\
\hline Peer group influence & 109 & 27.25 \\
\hline Availability of sellers & 211 & 52.75 \\
\hline Total & 400 & 100 \\
\hline
\end{tabular}

TABLE 9: Perceived harmfulness of alcohol

\begin{tabular}{|l|l|l|}
\hline Risk & No. of respondents & Percent \\
\hline Not harmful & 23 & 5.75 \\
\hline Don't know & 8 & 2 \\
\hline Slightly harmful & 177 & 44.25 \\
\hline Very harmful & 192 & 48 \\
\hline Total & 400 & 100 \\
\hline
\end{tabular}




\section{REFERENCES}

Udo, C. O., 2005. Alcohol and Drug Education, Department of Adult Education University of Ibadan, Ibadan 40-44.

Priest, C. O., 2008. Modern Textbook of Personal and Communal Health for Nurses, New York: Haper and Row Publishers 80-85.

Gureje, O., 2009. Alcohol Abuse and Dependence in an Urban Primary Case Clinic in Nigeria. Drug and Alcohol Dependence (30):180-165.

National Population Commission Data., 1991. Abuja, Nigeria.

Charles, C. N., 2007. Drug Abuse: Reduction and Prevention. A Paper Presented at a Symposium on the Nigeria Youth Organized by the Gift of Life Organization (Glo) At Futo Owerri.

Oladimeji, B. Y., 2006. Trend in Alcohol Consumption among Nigerian under Graduated I. S. Obot (Ed) Epidemiology and Control of Substance Abuse in Nigeria. Job Center of Research and Information on Substance Abuse.

Abiodun, O. A., 2007. Alcohol-Related Problems in Primary Health Care in Nigeria. Acta Psychiatric Scandinavia (6): 230-234.
Okafor, J. O., 2008. Principles of Healthful Living Onitsha, Erudite Publisher Limited 20-25.

Obot, J. C., 2006. Substance Use, Health and Social Welfare in Contemporary Africa Social Science and Medicine 2, (5): 500510.

Ironbar, F. O., 2006. Drug Use and Abuse among University Students. Nigerian Journal of Applied Psychiatric 2, (3): 21-25.

Sing, H., 2010. Some Factors Associated With Substance Abuse Among Secondary Schools Students In Trinidad and Tobago. Journal of Drug Education. 26, 80-90.

Desire, C. C., 2010. Alcohol Consumption Pattern among Women in A Rural Community in Nigeria Substance Use and a Misuse 35, (1-2): 497-587. 